\title{
Publisher Correction: Marking the decarbonization revolutions
}

Ryan Hanna (iD) and David G. Victor (D)

Correction to: Nature Energy https://doi.org/10.1038/s41560-021-00854-1, published online 3 June 2021.

In the version of this Comment originally published, the $y$-axis title in Fig. 1a was incorrect as 'Carbon intensity of electricity $\left(\mathrm{kgC} \mathrm{G}^{-1}\right)^{\text {') }}$ it should have been 'Carbon intensity of primary energy $\left(\mathrm{kgC} \mathrm{GJ}^{-1}\right)$ '. In addition, the text ' $\mathrm{RD} \& \mathrm{D}^{\prime}$ ' has been changed to 'research, development and demonstration' in the caption and $y$-axes of Fig. 3 . These errors have now been corrected.

Published online: 25 June 2021

https://doi.org/10.1038/s41560-021-00869-8

(c) The Author(s), under exclusive licence to Springer Nature Limited 2021 